\title{
Influence of understorey diversity on wildlife at the coal mining reclamation area in South Kalimantan, Indonesia
}

\author{
YUSANTO NUGROHO ${ }^{1}$, SUPANDI $^{2}$, SUYANTO $^{1}$, JERIELS MATATULA $^{3}$, \\ PANDU YUDHA ADI PUTRA WIRABUANA, ${ }^{4, \boldsymbol{v}}$ \\ ${ }^{1}$ Faculty of Forestry, Universitas Lambung Mangkurat. Jl. Ahmad Yani Km 36, Banjarbaru 70722, South Kalimantan, Indonesia \\ ${ }^{2}$ PT Borneo Indobara. Jl. Propinsi Km 180, Angsana, Tanah Bumbu 72275, South Kalimantan, Indonesia \\ ${ }^{3}$ Forestry Field Program, Politeknik Pertanian Negeri Kupang. Jl. Prof. Johanes, Lasiana, Kupang 85228, East Nusa Tenggara, Indonesia \\ ${ }^{4}$ Faculty of Forestry, Universitas Gadjah Mada. Jl. Agro No. 1. Bulaksumur, Sleman 55281, Yogyakarta, Indonesia \\ Telp./Fax.+62-274-548815, `email: pandu.yudha.a.p@ugm.ac.id
}

Manuscript received: 4 July 2021. Revision accepted: 16 August 2021.

\begin{abstract}
Nugroho Y, Supandi, Suyanto, Matatula J, Wirabuana PYAP. 2021. Influence of understorey diversity on wildlife at the coal mining reclamation area in South Kalimantan, Indonesia. Biodiversitas 22: 3736-3742. The existence of understorey at the coal mining reclamation area provides an important contribution to improve the environmental quality, especially the wildlife presence. Therefore, this study aims to determine the influence of understorey diversity on the wildlife at the coal mining reclamation area managed by the PT Borneo Indobara, South Kalimantan. This study used an ecological survey conducted in three reclamation areas classified based on the dominant species supporting the process, namely Paraserianthes falcataria (L-1), Anthocephalus cadamba (L-2), and a mixture of both species (L-3). The data were collected in two observation periods, namely August 2019 and August 2020. The results showed that at the first observation, ten families of understorey were observed from the survey and the highest diversity was recorded in $\mathrm{L}-2\left(\mathrm{H}^{\prime}=1.71\right)$, followed by L-1 $\left(\mathrm{H}^{\prime}=1.54\right)$, and L-3 ( $\left.\mathrm{H}^{\prime}=1.27\right)$. Meanwhile, the wildlife in the first periods was only 6 species consisting of 3 birds, 2 reptiles, and 1 mammal. The number of species from every site was relatively equal at the first observation. In the second observation, the diversity of understorey considerably increased with approximately 22 families from the inventory. The highest understorey diversity in this observation was recorded in L-1 ( $\left.\mathrm{H}^{\prime}=3.30\right), \mathrm{L}-2\left(\mathrm{H}^{\prime}=3.05\right)$, and L-3 $\left(\mathrm{H}^{\prime}=3.04\right)$. Also, the higher understorey diversity was followed by the higher wildlife with 29 species, which consists of 26 birds, 2 reptiles, and 1 mammal. The highest appearance of bird species was in the L-1 with approximately 19 species, while the number of birds in L-2 and L-3 was relatively similar with approximately 15 species. Based on these results, the understorey diversity significantly contributes to improving the wildlife diversity at the coal mining reclamation area, primarily from the bird species.
\end{abstract}

Keywords: Birds, ecological survey, environmental quality, mammals, post-mining, reptiles

\section{INTRODUCTION}

Coal mining is activities changing the landscape due to the use of an open pit in mining operations commonly referred to as open-cut mining. This method is carried out to excavate mineral deposits in a rock, which is suitable for horizontal ore bodies for high production at low costs (Marinin et al. 2021). Meanwhile, the open-pit mining system is carried out by clearing land, removing topsoil and rocks that cover the coal, and taking the coal using excavators and trucks (Setiawan et al. 2021). Therefore, coal mining activities influence changes in vegetation, soil structure, and geology, decrease the quality, and change the soil hydrology (Dejun et al. 2016). To anticipate these problems, successful land reclamation is required after excavation of coal deposits, which involves closing the mining hole and returning topsoil to cover the rock for revegetation activities. These reclamation and revegetation activities restore plant communities and ecosystems around mining to reduce the effects of mining operations on the environment (Buta et al. 2019).

Post-mining land reclamation activities were implemented at PT Borneo Indobara using fast-growing species such as Paraserianthes falcataria and Antocephalus cadamba with the addition of Pterocarpus indicus, Mangifera indica, Swietenia macrophylla, and Acacia mangium plants that grow naturally. Furthermore, understorey such as grass, ferns, and herbs are often overgrown, especially Acacia mangium, which grows naturally. Meanwhile, this understorey is considered a weed that disturbs the main crop, and the cleaning is sometimes carried out. The ecological clearing of land under the stands has an impact on decrease in the diversity of understorey which is important for the soil health in the reclamation area. Moreover, cleaning of understorey under tree stands in the reclamation area reduces the presence of fauna. Sasaki et al. (2015) stated that the changes in plant habitat in mining areas affect wildlife populations. A previous study by Partasasmita et al. (2017) stated that birds' use of vegetation space is divided into the lower stratum in the form of understorey plants and the upper in the form of tree crowns. Furthermore, Bradfer-Lawrence et al. (2018) stated that various species of birds like habitats in stratum $\mathrm{D}$ and $\mathrm{E}$ are dominated by understorey species. Therefore, the presence of fauna in the reclamation area is an indicator of land recovery after coal mining activities. 
The understorey plants in ecosystems play a very important role, namely a source of nutrients, germplasm, food for animals, and preventing erosion (Mestre et al. 2017). Hence, a study is required to determine the important role of understorey for the wildlife in the reclamation area, evaluate the level of animals, and analyze the presence of understorey after cleaning for one month and a year. This study aims to analyze the effect of understorey presence and diversity on the wildlife level of the birds, reptiles, and mammals in the reclamation area after coal mining.

\section{MATERIALS AND METHODS}

\section{Study area}

The site was located in the reclamation area of PT Borneo Indobara where the coal mining operation is carried out. This study was implemented in 14 months at different stages: field preparation, understorey cleaning, data collection, and analysis. Meanwhile, the observation was carried out in 2 stages, with the first in August 2019 and the second in 2020. The geographical coordinates of

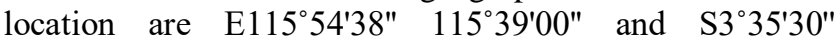
$3^{\circ} 36^{\prime} 30^{\prime \prime}$. The reclamation area is with 2 main species of plants, namely Paraserianthes falcataria and Antocephalus cadamba which were established in 2013. The site is administratively situated in Sungai Loban District, Tanah Bumbu Regency, South Kalimantan Province (Figure 1). The field survey was carried out in three sites of reclamations classified based on the dominant vegetation species (Table 1).

\section{Procedures}

This study was conducted in a reclamation area with plant species Paraserianthes falcataria and Antocephalus cadamba, and the two types of data collected include the presence and diversity of understorey and wildlife. The treatment was carried out by cleaning the understorey in the reclamation area in a manual and chemical combination, while land clearing was conducted once and observations were made subsequently. Moreover, field observations were conducted in two stages, where the first was after one month and the second after one year of understorey cleaning activities. During this one year, the understorey was allowed to grow and develop without any disturbance. At each stage of observation, identification of the presence of understorey species and wildlife species, such as birds, reptiles, and mammals was carried out. This treatment was carried out to identify the presence and diversity of understorey together with wildlife species after land clearing activities.

Table 1. Location of ecological survey for monitoring understorey diversity and wildlife presence at the coal mining reclamation area

\begin{tabular}{clcc}
\hline Site & \multicolumn{1}{c}{ Species } & Symbol & $\begin{array}{c}\text { Planting } \\
\text { year }\end{array}$ \\
\hline 1 & Paraserianthe falcataria & L-1 & 2013 \\
2 & Antocephalus cadamba & L-2 & 2013 \\
\multirow{2}{*}{3} & Mixed species & L-3 & 2013 \\
\hline
\end{tabular}

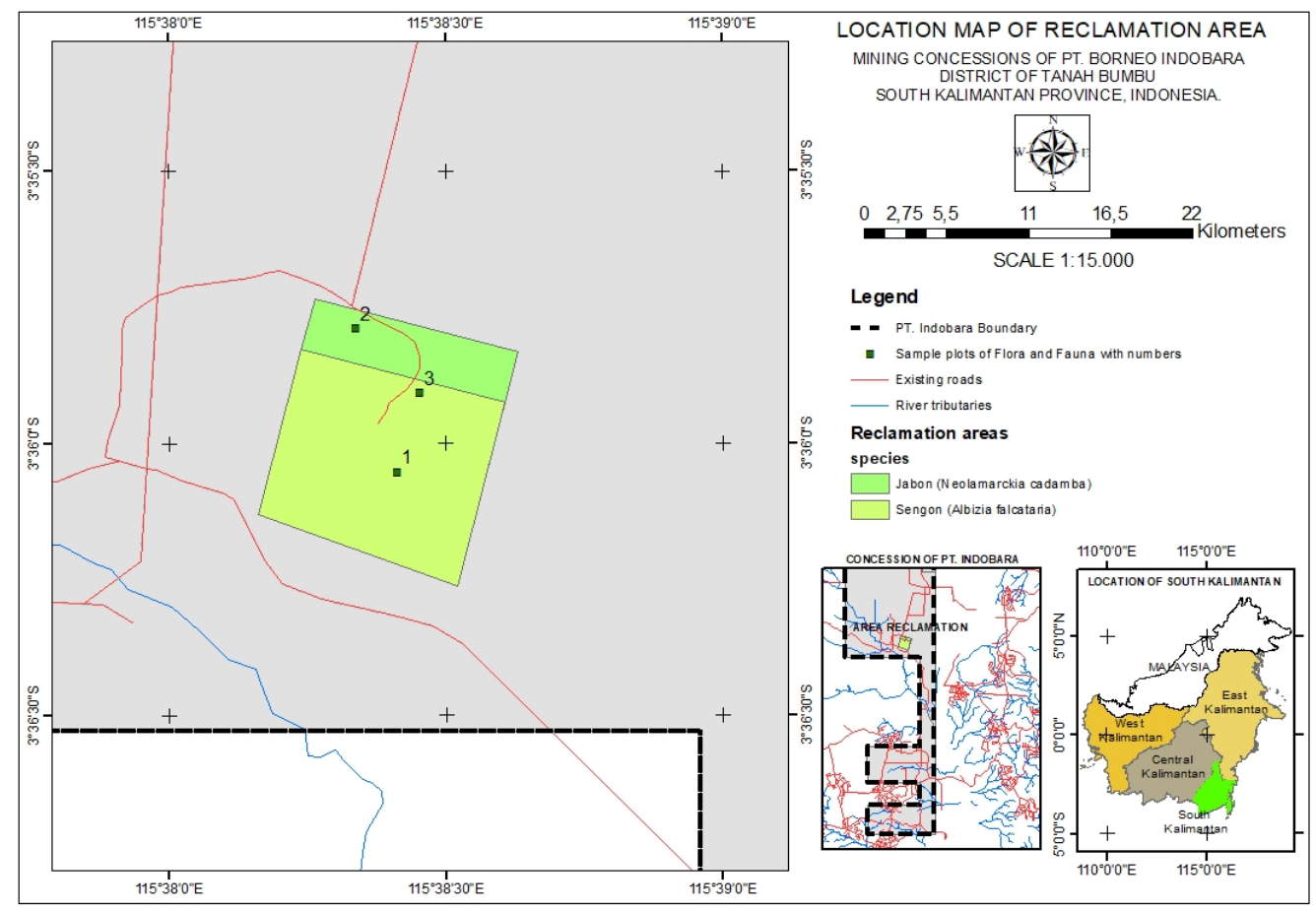

Figure 1. The study site of coal mining reclamation area in the PT Borneo Indobara. The number indicated the position of sampling location 
Understorey data were obtained using the transect-line method up to six measuring plots at each observation point. The measuring plot size was $2 \times 2 \mathrm{~m}$ and each was spaced at an interval of one plot to achieve a path length of $24 \mathrm{~m}$. Meanwhile, the observation data for understorey flora include species presence, relative frequency and density, important value index, and diversity of understorey species. The understorey recorded were grasses, herbs, ferns, and woody plant seedlings and were included in the observation plot.

Wildlife observation data were obtained at the understorey point using the sampling method with a circle radius of $25 \mathrm{~m}$, while each point data were recorded in the morning from 07.00 to 11.00 and the afternoon at 14.00 18.00. The data recorded include the types and the number of individual wildlife species encountered, consisting of bird species (bird fauna), mammals, and reptiles. The observed wildlife in form of birds was identified using MacKinnon et al. (2010). Furthermore, wildlife in form of mammals was identified by Francis (2013) or Payne et al. (2000), and those in form of reptiles were identified using Das (2010).

\section{Data analysis}

Analysis of understorey data using the formula to calculate the Important Value Index according to Lü et al. (2011), that is:

Relative density $=($ Density of a species $) /($ Density of all species $) \times 100$

Relative frequency $=($ Freq. of a species $) /($ Freq. of all species $) \times 100$

Important value index $=$ Relative density + Relative frequency

Importance Value Index (IVI) for understorey plants ranges from $0-200$. If the value is close to 200 , then a species has a higher ecological level in a community and if it is close to 0 , its ecological control is lower in the community. The diversity index is calculated using the formula by (Naidu and Kumar 2016), the formulation is as follows:

$\mathrm{H}^{\prime}=-(\mathrm{pi}) \ln (\mathrm{pi})$ where $\mathrm{pi}=\mathrm{ni} / \mathrm{N}$ where $\mathrm{H}^{\prime}$ was the Diversity index, ni indicates an abundance of every species, and $\mathrm{N}$ was the total sample observed. The greater $\mathrm{H}^{\prime}$ of a community indicates that the community is getting better. The value of $\mathrm{H}^{\prime}$ equal to 0 can occur if there is only one species in one sample and maximum $\mathrm{H}$ if all species have the same number of individuals and this indicates a perfectly distributed abundance. The criteria for the diversity index based on Shannon-Wiener was expressed below (Djufri et al. 2016):

The analysis of IVI was only applied for understorey vegetation while the determination of the Shannon-Wiener Index was done for understorey and wildlife.

\section{RESULTS AND DISCUSSION}

\section{Understorey diversity}

The results of the first stage of understorey identification showed that the presence of understorey species is 11 from 10 families (Table 3). These species naturally appear after land clearing treatment and are categorized as pioneer plants. Based on the calculation of the understorey at site L-1, there were six species with a diversity of 1.54 according to the Shannon-Wiener index having low criteria, while Melastoma candidum and Imperata cylindrica have the highest important value index. In the site observation of L-2, there were seven (thderstorey species from six families with a diversity of 1.71 having a low classification, while I. cylindrica and Blechnum orientale have an index value of the highest importance. Furthermore, in the site observation L-3, there were four species of understorey from four families with a diversity of 1.27 having a low classification, while $I$. cylindrica and Pueraria javanica have the highest importance value index.

Table 2. Criteria of diversity index based on Shannon-Wiener

\begin{tabular}{ll}
\hline H' value & Descriptions \\
\hline$<1$ & Low diversity \\
$1-3$ & Moderate diversity \\
$>3$ & High diversity \\
\hline
\end{tabular}

Table 3. Presence and diversity of understorey species on the reclamation area after one month of slashing

\begin{tabular}{|c|c|c|c|c|c|c|c|}
\hline \multirow{2}{*}{ Species } & \multirow{2}{*}{ Family } & \multicolumn{2}{|c|}{ L1 } & \multicolumn{2}{|c|}{$\mathbf{L 2}$} & \multicolumn{2}{|c|}{$\mathbf{L 3}$} \\
\hline & & $\mathbf{A P}$ & IVI & $\mathbf{A P}$ & IVI & $\mathbf{A P}$ & IVI \\
\hline Ageratum conyzoides & Asteraceae & $\checkmark$ & 7.3 & $\checkmark$ & 6.5 & & \\
\hline Blechnum orientale & Blechnaceaea & & & $\checkmark$ & 43.5 & & \\
\hline Brachiaria mutica & Gramineae & & & $\checkmark$ & 13.0 & & \\
\hline Imperata cylindrica & Poaceae & $\checkmark$ & 48.5 & $\checkmark$ & 71.2 & $\checkmark$ & 93.5 \\
\hline Macroptilium lathyroides & Palpilionaceae & & & $\checkmark$ & 17.8 & & \\
\hline Melastoma candidum & Melastomataceae & $\checkmark$ & 79.5 & & & & \\
\hline Passiflora foetida & Passifloraceae & & & & & $\checkmark$ & 26.8 \\
\hline Pueraria javanica & Fabaceae & $\checkmark$ & 14.6 & & & $\checkmark$ & 41.0 \\
\hline Pueraria phaseoloides & Palpilionaceae & $\checkmark$ & 20.1 & $\checkmark$ & 26.8 & & \\
\hline Scleria sp. & Cyperaceae & $\checkmark$ & 30.1 & & & $\checkmark$ & 38.7 \\
\hline Scoparia dulcis & Plantaginaceae & & & $\checkmark$ & 21.2 & & \\
\hline $\mathrm{H}^{\prime}$ of each observation site & & & & & & & \\
\hline $\mathrm{H}^{\prime}$ of entire reclamation site & & & & & & & \\
\hline
\end{tabular}

Note: AP (appearance); IVI (important value index); the checklist $(\checkmark)$ indicated the species has been found at the observation 
Table 4. Presence and diversity of understorey species observed in the reclamation area one year after understorey clearing

\begin{tabular}{|c|c|c|c|c|c|c|c|}
\hline \multirow{2}{*}{ Species } & \multirow{2}{*}{ Family } & \multicolumn{2}{|c|}{ L1 } & \multicolumn{2}{|c|}{ L2 } & \multicolumn{2}{|c|}{ L3 } \\
\hline & & $\mathbf{A P}$ & IVI & $\mathbf{A P}$ & IVI & $\mathbf{A P}$ & IVI \\
\hline Abelmoschus moschatus & Malvaceae & $\checkmark$ & 3.1 & & & & \\
\hline Acacia mangium & Fabaceae & $\checkmark$ & 6.7 & & & $\checkmark$ & 13.0 \\
\hline Ageratum conyzoides & Asteraceae & $\checkmark$ & 15.1 & $\checkmark$ & 16 & $\checkmark$ & 13.5 \\
\hline Anacardium ocidentale & Anacardiaceae & & & $\checkmark$ & 1 & & \\
\hline Arachis pintoi & Fabaceae & $\checkmark$ & 4.1 & $\checkmark$ & 7 & $\checkmark$ & 7.7 \\
\hline Asystasia gangetica & Acanthaceae & $\checkmark$ & 7.0 & $\checkmark$ & 7 & $\checkmark$ & 8.6 \\
\hline Bauhinia kockiana & Fabaceae & $\checkmark$ & 6.1 & $\checkmark$ & 7 & $\checkmark$ & 6.4 \\
\hline Blechnum orientale & Blechnaceae & $\checkmark$ & 5.5 & & & $\checkmark$ & 8.4 \\
\hline Boehmeria nivea & Urticaceae & $\checkmark$ & 2.6 & $\checkmark$ & 5 & $\checkmark$ & 9.3 \\
\hline Brachiria mutica & Graminaeae & $\checkmark$ & 6.5 & $\checkmark$ & 10 & & \\
\hline Byttneria maingayi & Malvaceae & & & $\checkmark$ & 7 & & \\
\hline Calopogium mucunoides & Leguminaceae & $\checkmark$ & 10.2 & $\checkmark$ & 11 & $\checkmark$ & 14.1 \\
\hline Cayratia trifolia & Vitaceae & $\checkmark$ & 4.9 & & & $\checkmark$ & 6.2 \\
\hline Centrosema molle & Fabaceae & $\checkmark$ & 4.9 & & & $\checkmark$ & 7.5 \\
\hline Chromolaena odorata, & Asteraceae & $\checkmark$ & 6.5 & $\checkmark$ & 8 & $\checkmark$ & 11.9 \\
\hline Cyperus eragrostis & Cyperaceae & & & $\checkmark$ & 6 & & \\
\hline Cyrtococcum patens & Poaceae & $\checkmark$ & 7.7 & & & & \\
\hline Dicranopteris linearis & Gleicheniaceae & $\checkmark$ & 6.7 & $\checkmark$ & 7 & & \\
\hline Fimbristylis littoralis & Cyperaceae & $\checkmark$ & 7.1 & $\checkmark$ & 8 & & \\
\hline Hyptis capitata & Lamiaceae & $\checkmark$ & 7.0 & $\checkmark$ & 7 & $\checkmark$ & 7.7 \\
\hline Imperata cylindrica & Poaceae & $\checkmark$ & 9.0 & $\checkmark$ & 15 & $\checkmark$ & 13.5 \\
\hline Ipomea cordatriloba & Convolvulaceae & & & $\checkmark$ & 6 & & \\
\hline Macaranga tanarius & Euphorbiaceae & $\checkmark$ & 6.0 & & & $\checkmark$ & 5.5 \\
\hline Mangifera indica & Anacardiaceae & $\checkmark$ & 5.6 & $\checkmark$ & 6 & & \\
\hline Melastoma candidum & Melastomataceae & $\checkmark$ & 16.5 & $\checkmark$ & 18 & $\checkmark$ & 15.2 \\
\hline Mimosa pudica & Fabaceae & $\checkmark$ & 6.0 & $\checkmark$ & 7 & $\checkmark$ & 8.6 \\
\hline Passiflora foetida & Passifloraceae & $\checkmark$ & 7.2 & $\checkmark$ & 8 & $\checkmark$ & 6.4 \\
\hline Phyllanthus reticulatus & Phyllanthaceae & $\checkmark$ & 5.5 & $\checkmark$ & 7 & $\checkmark$ & 8.4 \\
\hline Phyllanthus debilis & Phyllanthaceae & $\checkmark$ & 4.2 & & & $\checkmark$ & 8.6 \\
\hline Pterocarpus indicus & Fabaceae & & & & & $\checkmark$ & 4.6 \\
\hline Rhynchospora corymbosa & Cyperaceae & $\checkmark$ & 3.9 & & & & \\
\hline Scleria sp. & Cyperaceae & $\checkmark$ & 13.6 & $\checkmark$ & 13 & $\checkmark$ & 8.8 \\
\hline Swietenia macrophylla & Meliaceae & & & $\checkmark$ & 8 & & \\
\hline Syzygium aqueum & Myrtaceae & $\checkmark$ & 3.4 & & & & \\
\hline Uncaria cordata & Rubiaceae & $\checkmark$ & 4.5 & $\checkmark$ & 6 & $\checkmark$ & 6.0 \\
\hline Vitex pinnata & Lamiaceae & $\checkmark$ & 3.3 & & & & \\
\hline $\mathrm{H}^{\prime}$ of each observation site & & & & & & & \\
\hline $\mathrm{H}^{\prime}$ of entire reclamation site & & & & & & & \\
\hline
\end{tabular}

Note: AP (appearance); IVI (important value index); the checklist $(\checkmark)$ indicated the species has been found at the observation

Imperata cylindrica has fast adaptability to grow as a pioneer plant in reclamation areas where land clearing is carried out. This is because the roots of the reeds in form of rhizomes under the ground remain alive even though the top of the plant is damaged and fired (Soendjoto et al. 2014). This plant grows quickly in marginal soil conditions which makes it to be considered as weeds when shaded by other species with denser canopy densities (Kone et al. 2013). In addition, the $M$. candidum also has high adaptability because of its resistance to acid soils and ability to absorb aluminum toxins and the height is approximately 0.5-4 meters (Watanabe et al. 2005). Therefore, an increase in $M$. candidum suppresses the growth rate of I. cylindrica because the canopy is higher and denser.

The species diversity index in all plots in the reclamation area after one month of understorey cleaning showed a diversity index of 2.09 with a moderate level. Meanwhile, the species of understorey present after the land clearing are used to develop a land precondition to improve soil properties in the post-coal mining reclamation area. However, not all plants were able to grow and adapt to marginal soils after coal mining because the soil in the reclamation area has many limiting factors such as low porosity and high density (Noviyanto et al. 2017). Therefore, the presence of understorey species is considered an adaptive species to post-coal mining land.

The results of understorey identification after one year of understorey cleaning (Table 4) showed an increase in the number of individual presences and the index of species diversity in the reclamation area after it was allowed to grow and develop. Furthermore, the results showed that there were 36 species of understorey from 22 families. During this period, understorey was left undisturbed and there was an increase in the presence of understorey of approximately $327 \%$. Based on the calculation of the important value and the diversity index at location 1 , there were 30 understorey species from 22 families with a 
diversity of 3.15 having a high classification. At location 2, there were 24 species from 18 families with a diversity index of 2.91 and a moderate classification. Furthermore, at location 3, there were 22 understorey species from 15 families with a diversity index of 2.93 and a medium classification. Therefore, the species diversity index in all plots in the reclamation area during observations of one year after slashing showed a value of 3.35 with a high classification.

Furthermore, $M$. candidum at all observation locations has the highest IVI, which showed that these species are capable of becoming a pioneer with high adaptation in post-coal mining areas. Meanwhile, I. cylindrica which initially had an IVI similar to the $M$. candidum was observed one year after cleaning and shifted by other species, such as Ageratum conyzoides. A previous study by Komara et al. (2016) showed that A. conyzoides observed 16 years after reclamation had an important value index of the third order of 29 species in the post-coal mining reclamation area in East Kalimantan. Meanwhile, several species of the understorey in form of woody plant seedlings in the reclamation area that grow and develop naturally include Macaranga tanarius, Syzygium aqueum, and Vitex pinnata. Also, several woody plants in the seedling phase are included in the observation plot and are present due to planting, including Mangifera indica, Pterocarpus indicus, and Swietenia macrophylla.

Out of the 36 species of understorey presented in the reclamation area after 1 year of cleaning activities, 15 were always present at the three observation locations. Meanwhile, one of these species is Chromolaena odorata, which grows on marginal and fertile land (Hamdani et al. 2017). The growth of this plant on land produces litter that contains a lot of nutrients due to its suitability as raw material for making compost. It also suppresses the growth of I. cylindrica (Juniarti 2017). Therefore, soil improvement with the presence of understorey and higher vegetation improves the function of complex ecosystems, from microorganisms to macroorganisms (Pan et al. 2018).

The species of $M$. candidum which dominates the important values in all observation locations produces several flowers as a source of food for various species of insects and flower-eating birds. Moreover, the variety of understorey that produces flowers attracts wild animals such as birds, mammals, reptiles, amphibians, and insects to migrate to the reclamation area in search of food sources.

\section{Wildlife presence}

The identified wildlife includes birds, reptiles, and mammals. The identification of the bird fauna (Table 5) showed that there is a change in its presence and diversity which is significantly high within an increase in the understorey. The classification of species presence and diversity index in the observation of one month after cleaning activities were 3 species with an index of 0.90 $\left(\mathrm{H}^{\prime}=\right.$ low), while 26 were observed one year after cleaning activities with an index of $3.35\left(\mathrm{H}^{\prime}=\right.$ high$)$. According to
Casas et al. (2016), the presence and diversity of birds are strongly influenced by the composition and structure of vegetation. Similarly, changes in the structure of vegetation including understorey, saplings, poles, and trees affect the presence of animals. The existence of food sources and habitat suitability attract animals' migration to the reclamation area until the reclaimed plants become a climax. A previous study (Boer 2009) showed that in the area of land reclamation and rehabilitation, the presence of bird fauna changes continuously towards the common composition in natural forests.

Birds are the most common indicator of animals and are often used to detect and respond quickly to environmental changes (Wong and Candolin 2015). During observation after the understorey cleaning activities, the habitat of birds and other animals changes, which leads to migration to an undisturbed area. According to (Liang et al. 2021), the community of bird species declines and migrates due to a decrease in suitable habitat. Meanwhile, habitat is improved through the process of succession of the understorey in the reclamation area by allowing it to grow and develop for one year without disturbance. Also, the presence of understorey increases to show high diversity, which makes the bird community reappear until it reaches a high classification index. A previous study (Swab et al. 2017) showed that the initial success of reclamation areas in form of grass contributed to the increase in songbird populations. The development of birds and other animals evolves gradually with the succession of plants. Therefore, the use of mining land reclamation methods to create biodiversity determines the rate of presence and composition of bird species (Al-Reza et al. 2016)

The bird fauna in the reclamation area after one year of understorey cleaning activities were approximately $7.70 \%$ and categorized as water birds, such as Todiramphus Chloris, Actitis hypoleucos. Out of the $92.30 \%$ of the water birds, as described by Ducks Unlimited New Zealand (2017), there are 8 families on the west coast and 34 in the world, and 33 as described by Wetlands International (2020). The presence of waterbirds in the reclamation area is due to the availability of former mining pit water sources close to the area.

The wildlife is not only dependent on plants, but animals also influence the presence and condition of plants because vegetation requires birds, mammals, or other animals for pollination (Ratto et al. 2018). Meanwhile, many species of birds often forage and make nests in the stratum of understorey such as Orthotomus ruficeps, Prinia flaviventris, Centropus bengalensis, Rhipidura javanica, Lanius schach, Lonchura punctulata, etc. The diversity of understorey and high-density isi a good habitat for various animals to grow and develop (Valladares et al. 2016). Birds or small animals, such as Orthotomus ruficeps and Prinia flaviventris, hide in thickets of leaves/shrubs from predators. Similarly, Centropus bengalensis likes short trees with thick understorey for foraging, playing, sheltering, and nesting (Rajpar and Zakaria 2011). 
Table 5. Presence and diversity of bird fauna in the reclamation area during observations one month and one year after understorey cleaning

\begin{tabular}{|c|c|c|c|c|c|c|c|}
\hline \multirow{2}{*}{ Species } & \multirow{2}{*}{ Family } & \multicolumn{3}{|c|}{ First observation } & \multicolumn{3}{|c|}{ Second observation } \\
\hline & & L-1 & L-2 & L-3 & L-1 & L-2 & L-3 \\
\hline Gerygone sulphurea & Acanthizidae & & & & $\checkmark$ & & $\checkmark$ \\
\hline Aegithina tiphia & Aegithinidae & & & & $\checkmark$ & & $\checkmark$ \\
\hline Todiramphus chloris & Alcedinidae & & & & $\checkmark$ & & \\
\hline Artamus leucoryn & Artamidae & $\checkmark$ & & & & & $\checkmark$ \\
\hline Caprimulgus affinis & Caprimulgidae & & & & $\checkmark$ & & \\
\hline Orthotomus ruficeps & Cisticolidae & & & & $\checkmark$ & $\checkmark$ & $\checkmark$ \\
\hline Prinia flaviventris & Cisticolidae & & & & $\checkmark$ & $\checkmark$ & $\checkmark$ \\
\hline Geopelia striata & Columbidae & & & & $\checkmark$ & & $\checkmark$ \\
\hline Spilopelia chinensis & Columbidae & $\checkmark$ & $\checkmark$ & $\checkmark$ & $\checkmark$ & & \\
\hline Centropus bengalensis & Cuculidae & & & & & & $\checkmark$ \\
\hline Dicaeum trochileum & Dicaeidae & & & & $\checkmark$ & $\checkmark$ & \\
\hline Dicaeum trigonostigma & Dicaeidae & & & & $\checkmark$ & & \\
\hline Lonchura punctulata & Estrildidae & & & & $\checkmark$ & $\checkmark$ & $\checkmark$ \\
\hline Hirundinidae & Estrildidae & & & & & & \\
\hline Hirundo rustica & Estrildidae & & & & & $\checkmark$ & $\checkmark$ \\
\hline Hirundo tahitica & Estrildidae & & & & $\checkmark$ & & $\checkmark$ \\
\hline Lanius schach & Laniidae & & & & & & $\checkmark$ \\
\hline Meropidae & Laniidae & & & & & & \\
\hline Merops viridis & Laniidae & & & & & $\checkmark$ & $\checkmark$ \\
\hline Nectariniidae & Laniidae & & & & & & \\
\hline Anthreptes malacensis & Laniidae & & & & $\checkmark$ & $\checkmark$ & \\
\hline Cinnyris jugularis & Laniidae & & & & & $\checkmark$ & \\
\hline Dendrocopos moluccensis & Picidae & & & & $\checkmark$ & $\checkmark$ & $\checkmark$ \\
\hline Pycnonotidae & Picidae & & & & & & \\
\hline Pycnonotus aurigaster & Picidae & & & & $\checkmark$ & $\checkmark$ & $\checkmark$ \\
\hline Pycnonotus goiavier & Picidae & $\checkmark$ & $\checkmark$ & $\checkmark$ & $\checkmark$ & $\checkmark$ & \\
\hline Rhipiduridae & Picidae & & & & & & \\
\hline Rhipidura javanica & Picidae & & & & $\checkmark$ & $\checkmark$ & \\
\hline Actitis hypoleucos & Scolopacidae & & & & & & $\checkmark$ \\
\hline Sturnidae & Scolopacidae & & & & & & \\
\hline Acridotheres javanicus & Scolopacidae & & & & $\checkmark$ & $\checkmark$ & $\checkmark$ \\
\hline Vangidae & Scolopacidae & & & & & & \\
\hline Hemipus hirundinaceus & Scolopacidae & & & & $\checkmark$ & $\checkmark$ & $\checkmark$ \\
\hline $\mathrm{H}^{\prime}$ of each observation site & & 0.69 & 0.64 & 0.64 & 2.90 & 2.69 & 2.77 \\
\hline $\mathrm{H}^{\prime}$ of entire reclamation site & & & 0.90 & & & 3.17 & \\
\hline
\end{tabular}

Note: the checklist $(\checkmark)$ indicated the species has been found at the observation

Table 6. Presence and diversity of reptiles and mammal fauna in the reclamation area during observations one month and one year after cleaning the understory

\begin{tabular}{llcc}
\hline \multicolumn{1}{c}{ Species } & Family & $\begin{array}{c}\text { First } \\
\text { observation }\end{array}$ & $\begin{array}{c}\text { Second } \\
\text { observation }\end{array}$ \\
\hline Bronchocela jubata & Agamidae & $\checkmark$ & $\checkmark$ \\
Eutropis multifasciata & Scincidae & $\checkmark$ & $\checkmark$ \\
Varanus salvator & Varanidae & & $\checkmark$ \\
Callosciurus notatus & Sciuridae & $\checkmark$ & \\
H' of entire reclamation site & 1.10 & 1.10 \\
\hline
\end{tabular}

Note: the checklist $(\checkmark)$ indicated the species has been found at the observation

Clean puddles are a habitat for animals to breed and also a source of food. Hence, the pool at the reclamation area is a place for animals to drink and find food, especially the waterbird Todiramphus chloris. In a puddle, dragonfly larvae develop, and after adulthood are food for Merops viridis and other insectivore species consuming flying insects (Arbeiter et al. 2014).
There are three species of non-bird fauna in the reclamation area as shown by the observation of one month after the understorey cleaning activities, namely Eutropis multifasciata, Bronchocela jubata, and Callosciurus notatus. Meanwhile, one year after the understorey cleaning, E. multifasciata, B. jubata, and Varanus salvator were discovered (Table 6).

The non-bird fauna species were identified as 1 species of mammal, namely $C$. notatus, and 3 species of reptiles, namely B. jubata, E. multifasciata, and $V$. salvator. They were obtained by the direct encounter. Meanwhile, the recovery of reptiles and mammals species in the reclamation land was slower than the avian fauna species. The factor of stand density and the availability of food sources significantly influenced the encounter of this mammal species. In the rehabilitated ex-coal mining area with a plant age of up to 10 years in a dense understorey condition, 15 species of mammals were discovered (Soendjoto et al. 2015). Hence, establishing a microclimate under the stands and suitable atmosphere with a variety of plants as a source of food is required for animals 
to find food, rest, play, hide from predators, sing, and breed.

Based on these results, the increase in the diversity of understorey in the reclamation area attracts the presence of birds fauna. The development of understorey and woody plants to resemble natural forest habitats makes birds, reptiles, and mammal fauna migrate to the reclamation area. Therefore, understorey provides a place for animals to rest, hide, shelter, nest, find food, make sounds, and breed.

\section{ACKNOWLEDGEMENTS}

The authors are grateful to the PT Borneo Indobara that supports this study in their concession area. Furthermore, the authors are grateful to Kinanto Prabu Werdana, Yudha Hadiyanto Eka Saputra, and Chairul Anwar for facilitating the field survey.

\section{REFERENCES}

Al-Reza DD, Prasetyo LB, Hermawan R. 2016. Biodiversity of plants and birds in reclamation area of PT bukit Asam, Muara Enim, South Sumatera. Jurnal Manajemen Hutan Tropika 22 (3): 158-168. DOI: 10.7226/jtfm.22.3.158 [Indonesian]

Arbeiter S, Schnepel H, Uhlenhaut K, Bloege Y, Schijlze M, Hahn S. 2014. Seasonal shift in the diet composition of european bee-eaters Merops apiaster at the northern edge of distribution. Ardeola 61 (1): 161-170. DOI: 10.13157/arla.61.1.2014.161

Boer C. 2009. Variety of avifauna on land ex-gold mining PT Kelian equatorial mining West Kutai, East Kalimantan. Jurnal Manajemen Hutan Tropika 15 (2): 54-60. DOI: 10.7226/jmht.15.2. [Indonesian]

Buta M, Blaga G, Paulette L, Păcurar I, Roşca S, Borsai O, Grecu F, Sînziana PE, Negruşier C. 2019. Soil reclamation of abandoned mine lands by revegetation in Northwestern part of Transylvania: A 40-Year retrospective study. Sustainability 11: 1-18. DOI: 10.3390/su10023393.

Bradfer-Lawrence T, Gardner N, Dent DH. 2018. Canopy bird assemblages are less influenced by habitat age and isolation than understory bird assemblages in Neotropical secondary forest. Ecol Evol 8 (11): 5586-5597. DOI: 10.1002/ece3.4086.

Casas G, Darski B, Ferreira PMA, Kindel A, Müller SC. 2016. Habitat structure influences the diversity, richness and composition of bird assemblages in successional Atlantic rain forests. Trop Conserv Sci 9 (1): 503-524. DOI: 10.1177/194008291600900126.

Das I. 2010. A Field Guide to The Reptiles of Southeast Asia. New Holland Publishers Ltd, London.

Dejun Y, Zhengfu B, Shaogang L. 2016. Impact on soil physical qualities by the subsidence of coal mining: a case study in Western China. Environ Earth Sci 75 (8): 1-14. DOI: 10.1007/s12665-016-5439-2.

Djufri, Wardiah, Muchlisin ZA. 2016. Plants diversity of the deforested peat-swamp forest of Tripa, Indonesia. Biodiversitas 17 (1): 372-376 DOI: $10.13057 /$ biodiv/D170150.

Ducks Unlimited New Zealand. 2017. What are waterbirds? https: //ducks.org.nz.

Francis CM. 2013. Mammals of South-East Asia. New Holland Publishers Ltd, London.

Hamdani AD, Sulityowati E, Khusnuryani A. 2017. Soil improvemen potential of weeds biomass applied as green manure in marginal land. Trop Dry 1 (1): 12-16. DOI: 10.13057/tropdrylands/t010103.

Komara LL, Choesin DN, Syamsudin TS. 2016. Plant diversity after sixty years post-coal mining in East Kalimantan, Indonesia. Biodiversitas 17: 531-538.-DOI: 10.13057/biodiv/d170220.

Kone B, Amadji GL, Toure A, Togola A, Mariko M, Huat J. 2013. A case of Cyperus spp. and Imperata cylindrica occurrences on acrisol of the Dahomey gap in south Benin as affected by soil characteristics: A strategy for soil and weed management. Appl Environ Soil Sci 13: 17. DOI: $10.1155 / 2013 / 601058$.

Liang J, Peng Y, Zhu Z, Li X, Xing W, Li X, Yan M, Yuan Y. 2021. Impacts of changing climate on the distribution of migratory birds in
China: Habitat change and population centroid shift. Ecol Indic 127. DOI: 10.1016/j.ecolind.2021.107729.

Lü XT, Yin JX, Tang JW. 2011. Diversity and composition of understory vegetation in the tropical seasonal rain forest of Xishuangbanna, SW China. Rev Biol Trop 59 (1): 455-463. DOI: 10.15517/rbt.v59i1.3212

Juniarti. 2017. Chromolaena odorata compost affected soil chemical and rice crops (Oryza sativa L.). Agrotechnology 6 (1): 1-6. DOI: 10.4172/2168-9881.1000155.

MacKinnon J, Phillipps K, van Balen B. 2010. Field Guide of Birds in Sumatra, Kalimantan, Java and Bali. Puslitbang Biologi LIPI, Bogor.

Marinin M, Marinina O, Wolniak R. 2021. Assessing of losses and dilution impact on the cost chain: Case study of gold ore deposits. Sustainability 13 (7): 1-18. DOI: 10.3390/su13073830.

Mestre L, Toro-Manríquez M, Soler R, Huertas-Herrera A, MartínezPastur G, Lencinas MV. 2017. The influence of canopy-layer composition on understory plant diversity in southern temperate forests. For Ecosyst 4 (1): 1-13. DOI: 10.1186/s40663-017-0093-z.

Naidu MT, Kumar OA. 2016. Tree diversity, stand structure, and community composition of tropical forests in Eastern Ghats of Andhra Pradesh, India. J Asia-Pac Biodivers 9 (3): 328-334. DOI: 10.1016/j.japb.2016.03.019.

Noviyanto A, Purwanto P, Minardi S, Supriyadi S. 2017. The assessment of soil quality of various age of land reclamation after coal mining: a chronosequence study. Journal of Degraded and Mining Lands Management 5: 1009-1018.-DOI: 10.15243/jdmlm.2017.051.1009.

Pan P, Zhao F, Ning J, Zhang L, Ouyang X, Zang H. 2018. Impact of understory vegetation on soil carbon and nitrogen dynamic in aerially seeded Pinus massoniana plantations. PLoS ONE 13 (1): e0191952. DOI: 10.1371/journal.pone.0191952.

Partasasmita R, Atsaury ZIA, Husodo T. 2017. The use of forest canopy by various bird species in tropical forest montana zone, the Nature Reserve of Mount Tilu, West Java, Indonesia. Biodiversitas 18 (2): 453-457. DOI: 10.13057/biodiv/d180202.

Payne J, Francis CM, Phillipps K, Kartikasari SN. 2000. Panduan Lapangan Mamalia di Kalimantan, Sabah, Sarawak \& Brunei Darussalam. WCS Indonesia, Bogor.

Rajpar MN, Zakaria M. 2011. Bird species abundance and their correlationship with microclimate and habitat variables at natural wetland reserve, peninsular Malaysia. Intl J Zool 11: 1-17. DOI: $10.1155 / 2011 / 758573$.

Ratto F, Simmons BI, Spake R, Zamora-Gutierrez V, MacDonald MA, Merriman JC, Tremlett CJ, Poppy GM, Peh KSH, Dicks L V. 2018. Global importance of vertebrate pollinators for plant reproductive success: a meta-analysis. Front Ecol Environ 16 (2): 82-90. DOI: $10.1002 /$ fee. 1763 .

Sasaki K, Lesbarreres D, Watson G, Litzgus J. 2015. Mining-caused changes to habitat structure affect amphibian and reptile population ecology more than metal pollution. Ecol Appl 25 (8): 2240-2254. DOI: $10.1890 / 14-1418.1$.

Setiawan IE, Zhang Z, Corder G, Matsubae K. 2021. Evaluation of environmental and economic benefits of land reclamation in the Indonesian coal mining industry. Resources 10 (6): 60. DOI: 10.3390/resources10060060.

Soendjoto MA, Dharmono, Mahrudin, Riefani MK, Triwibowo D. 2014. Plant species richness after revegetation on the reclaimed coal mine land of PT Adaro Indonesia, South Kalimantan. Jurnal Manajemen Hutan Tropika 20 (3): 150-158. DOI: 10.7226/jtfm.20.3.150.

Soendjoto MA, Riefani MK, Triwibowo D, Novie M. 2015. Fauna in the reclamation area of PT Adaro Indonesia, South Kalimantan, after revegetated less than two years. Seminar Nasional Konservasi dan Pemanfaatan Sumberdaya Alam. FKIP UNS, Surakarta. [Indonesian]

Swab RM, Lorenz N, Byrd S, Dick R. 2017. Native vegetation in reclamation: Improving habitat and ecosystem function through using prairie species in mine land reclamation. Ecol Eng 108: 525-536. DOI: 10.1016/j.ecoleng.2017.05.012.

Valladares F, Laanisto L, Niinemets Ü, Zavala MA. 2016. Shedding light on shade: ecological perspectives of understorey plant life. Plant Ecol Divers 9 (3): 237-251. DOI: 10.1080/17550874.2016.1210262.

Watanabe T, Jansen S, Osaki M. 2005. The beneficial effect of aluminium and the role of citrate in $\mathrm{Al}$ accumulation in Melastoma malabathricum. New Phytol 165 (3): 773-780. DOI: 10.1111/j.14698137.2004.01261.x.

Wetlands International. 2020. Waterbird Population Estimates. https: //wpe.wetlands.org.

Wong BBM, Candolin U. 2015. Behavioral responses to changing environments. Behav Ecol 26 (3): 665-673. DOI: 10.1093/beheco/aru183. 